\title{
Examination of the terrestrial algae of the Great Smoky Mountains National Park, USA
}

\author{
Liliya S. Khaybullina ${ }^{1}$, Lira A. Gaysina ${ }^{1 *}$, Jeffrey R. Johansen ${ }^{2}$ \& Markéta \\ KRAUTOVÁ ${ }^{3}$ \\ ${ }^{I}$ Department of Botany, Bioecology and Landscape Design, Bashkir State Pedagogical University named after \\ M.Akmullah, Ufa, Oktyabrskoy revolucii st., 3a, 450000, Bashkortostan, Russia; \\ * corresponding author e-mail: lira.gaisina@gmail.com \\ ${ }^{2}$ Department of Biology, John Carroll University, University Heights, Ohio 44118, USA; \\ e-mail: johansen@jcu.edu \\ ${ }^{3}$ Faculty of Science, University of South Bohemia, České Budějovice, Branišovská 31, CZ-370 05, Czech \\ Republic
}

\begin{abstract}
Forest soils of the Great Smoky Mountains National Park were examined for soil algae as part of the All Taxa Biodiversity Inventory underway in that park. Soils of both mature and secondary growth forests were sampled, along with samples from rocks and tree bark. A total of 42 taxa were observed, representing Cyanobacteria (3 species), Chlorophyceae (12 species), Trebouxiophyceae (18 species), Ulvophyceae (3 species), Klebsormidiophyceae (1 species), Zygnematophyceae (2 species), Tribophyta (3 species), Eustigmatophyta (1 species), Euglenophyta (1 species), and Dinophyta (1 species). Twenty new taxa records for the park were established.
\end{abstract}

Key words: aerial algae, Chlorophyceae, Cyanobacteria, forest soils, phycobiont, terrestrial algae, Trebouxiophyceae.

\section{Introduction}

The Great Smoky Mountains National Park (GSMNP), an International Biosphere Preserve in the Appalachian Mountains, straddles the Tennessee-North Carolina border within the USA. Damp climate, coupled with the range of elevation and the southwest to northeast layout of these mountains, accounts for the striking diversity of living organisms found in the park. Five forest types within the park support over 1500 species of seed plants, 68 species of ferns and fern allies, and 484 bryophytes. Great Smoky Mountains National Park has a moderate climate, typified by mild winters and hot, humid summers. The variable topography can drastically affect local weather.

The first data concerning algal diversity in the Great Smoky Mountains dates back to 1949 (SILVA 1949). Recent examination of the algae of the park began with the All Taxa Biodiversity Inventory (ATBI) in 1997; with the first results published in 2004 by JOHANSEN et al. (2004). They listed 584 taxa in diverse phyla of algae. With more intensive study, the number of the algae was eventually catalogued at 1000 taxa (JOHANSEN et al. 2007). These algae were found in rivers, creeks, springs, and seep walls. Soil algae were studied in a very limited fashion by DEASON \& HeRndon (1989), who reported three taxa from soils in the park.

This paper reports the results of our examination of soil algae in the park. In addition to soils, we also sampled aerial algae on tree bark and wet rocks. Given the geographical size of the park and its diversity in geology, soils and vegetation, our study must be considered preliminary. We document our taxa with illustrations and short descriptions so that the variability within Great Smoky Mountains populations is recorded.

\section{Materials and Methods}

Samples were chosen to maximize representation of forests dominated by different species of trees and shrubs. We collected soils of both young forest ( 9 samples) and mature forest (8 samples). Wet rock (10) and wood (8 samples) biotopes were additionally 
sampled. A total of 39 samples from seven sites within the park were sampled (Table 1).

During a field expedition in the northern part of the GSMNP in August of 2006, the above samples were collected along five trails: Baskins Creek Trail, Grotto Falls (Trillium Gap Trail), Laurel Falls Trail, Ground Nature Trail, and Noland Divide Trail. We chose to study the soils of the basic ecosystem in the park forest. The forest sites differed in age and composition of trees. Five major forest types were sampled: The Cove Hardwood Forest, The Spruce-Fir Forest, Northern Hardwood Forest, Hemlock Forest, and Pine-Oak Forest. Mature forest in our study contained Quercus, Tsuga, and Acer. Younger forest contained Acer, Betula, Picea, Abies, and Rhododendron. They differed in light exposure, soil texture, and amount of understory foliage. The $\mathrm{pH}$ of the soil was very acidic, from $\mathrm{pH} 3.8$ to $\mathrm{pH}$ 5.8. In addition to the trails, two roadside sites were also chosen which had wet rock faces (Table 1).

All samples were divided into fresh and preserved portions. Unpreserved material was used for enrichment cultures, dilution-plate isolations, and DNA isolation. Enrichment cultures of aerial algae were made by dilution plating onto agar-solidified Z8 medium (CARMichael 1986). All cultures were maintained in a growth chamber at John Carroll University at 200 $\mu \mathrm{E} \cdot \mathrm{cm}^{-1}$ irradiance, on a $16: 8$ hour light:dark cycle, with temperature controlled at $18^{\circ} \mathrm{C}$ during the light cycle and $10^{\circ} \mathrm{C}$ during the dark cycle. Cultures were allowed to grow for 2-4 weeks prior to beginning analysis. All taxa were examined and photographed using an Olympus BH2 photomicroscope with high resolution Nomarski DIC optics, or with an Olympus
BX60 microscope with high resolution Nomarski DIC optics and a Diagnostic Instruments Spot Digital Camera.

Taxonomic determinations were made using standard references. For Cyanobacteria, GEITLER (1932), and KomÁrek \& ANAgnostidis (1999, 2005) were the primary references for species, with generic assignments following the recent revisions of Komárek and Anagnostidis (AnAgnostidis \& KomÁreK 1985, 1988, 1990; KomÁREK \& ANAGNOSTIDis 1986, 1989). References used for identifying green algae were diverse (Starmach 1972; EtTl 1983; KomÁReK \& Fott 1983; Moshrova \& Gollerbach 1986; EtTl \& GÄRTNER 1988, 1995; LOKHORST 1996; ANDREYEVA 1998). For Xanthophytes and Eustigmatophytes the primary resources were: DedusenKo-ShChegoleva \& Gollerbach (1962): Starmach (1968), Ettl (1978), Matvienko \& Dogadina (1978), and Ettl \& Gärtner (1995). The euglenoids were identified using WOŁOWSKI \& HINDÁK (2005).

\section{Results}

Forty-two taxa representing seven divisions of algae were found in the soils of the GSMNP: Cyanobacteria, Chlorophyta (Chlorophyceae, Trebouxiophyceae, Ulvophyceae), Charophyta (Klebsormidiophyceae, Zygnematophyceae), Tribophyta, Eustigmatophyta, Euglenophyta, and Dinophyta. Most of these algal species were unicellular coccoids. Twenty new taxon records

Table 1. Collecting sites for the terrestrial algae of the GSMNP study. Multiple samples were taken along trails during 7-8 August 2006 (indicated with letters in the text, e.g. 2A, 2B, 2C etc.). Abbreviations: (No.) number of samples collected from this site, (B) tree bark, (R) rock, (S) soil, (NC) North Carolina, (TN) Tennessee.

\begin{tabular}{|c|c|c|c|c|}
\hline Site & No & Location & Biotope & Habitat \\
\hline 1 & 3 & $\begin{array}{l}\text { Laurel Creek Road, TN } \\
35^{\circ} 38^{\prime} 56.8^{\prime \prime} \mathrm{N} ; 83^{\circ} 42^{\prime} 55.6^{\prime \prime} \mathrm{W}\end{array}$ & $\mathrm{R}$ & Wet cliff face by tunnel \\
\hline 2 & 8 & $\begin{array}{l}\text { Baskins Creek Trail, TN } \\
35^{\circ} 41^{\prime} 44.1^{\prime \prime} \mathrm{N} ; 83^{\circ} 28^{\prime} 28.9^{\prime \prime} \mathrm{W}\end{array}$ & $\mathrm{B}, \mathrm{S}$ & Young maple forest \\
\hline 3 & 4 & $\begin{array}{l}\text { Trillium Gap Trail, TN } \\
35^{\circ} 40^{\prime} 27.8^{\prime \prime} \mathrm{N} ; 83^{\circ} 28^{\prime} 56.9^{\prime \prime} \mathrm{W}\end{array}$ & B-, S & Old growth hemlock forest \\
\hline 4 & 4 & $\begin{array}{l}\text { Roaring Fork Motor Trail, TN } \\
35^{\circ} 42^{\prime} 38.8^{\prime \prime} \mathrm{N} ; 83^{\circ} 28^{\prime} 54.9^{\prime \prime} \mathrm{W}\end{array}$ & $\mathrm{R}$ & Wet cliff face by road \\
\hline 5 & 8 & $\begin{array}{l}\text { Laurel Falls Trail, TN } \\
35^{\circ} 40^{\prime} 42.6^{\prime \prime} \mathrm{N} ; 83^{\circ} 35^{\prime} 43.3^{\prime \prime} \mathrm{W}\end{array}$ & $\mathrm{B}, \mathrm{R}, \mathrm{S}$ & Old growth hemlock forest \\
\hline 6 & 4 & $\begin{array}{l}\text { Chimneys Nature Trail, TN } \\
35^{\circ} 38^{\prime} 08.3^{\prime \prime} \mathrm{N} ; 83^{\circ} 29^{\prime} 42.1^{\prime \prime} \mathrm{W}\end{array}$ & $\mathrm{S}$ & Old growth hardwood forest \\
\hline 7 & 8 & $\begin{array}{l}\text { Noland Divide Trail, NC } \\
35^{\circ} 33^{\prime} 12.0^{\prime \prime} \mathrm{N} ; 83^{\circ} 46^{\prime} 46.8^{\prime \prime} \mathrm{W}\end{array}$ & $\mathrm{B}, \mathrm{R}, \mathrm{S}$ & Young spruce forest on ridgetop \\
\hline
\end{tabular}


for the park were found, including: Botryidiopsis arhiza, Bracteacoccus medionucleatus, Chlorolobion lunulatum, Chlorosarcina cf. elegans, Chlorosarcina cf. rivulare, Choricystis minor, Dictyochloropsis splendida, Elliptochloris reniformis, Euglena mutabilis, Fernandiella alpina, Heterococcus sp., Keratococcus raphidioides, Lobochlamys cf. culleus, Myrmecia biatorellae, Myrmecia incisa, Neospongiococcum commatiforme, Pseudococcomyxa simplex, Raphidonemasempervirens, Spongiochlorisminor, and Stichococcus minor. The most widespread and frequent taxa were Stichococcus bacillaris, Klebsormidium flaccidum, Bracteococcus minor, and Pseudococcomyxa simplex. The majority of new species records were isolated into culture for further study.

In the taxonomic section we report wellknown and well-described taxa with abbreviated descriptions and original drawings. A number of species are poorly known, and we provide more lengthy descriptions of these algae. If taxa do not fit existing descriptions, deviations from these descriptions are reported.

\section{Taxonomic Section}

\section{Cyanobacteria}

\section{Chroococcus helveticus NäGELI (Figs 1, 2)}

Site: GSM 4D; damp rocks.

Cells 5.5-6 $\mu \mathrm{m}$ in diameter, with mucilage layer 2.5-3.5 $\mu \mathrm{m}$.

This species was found in uncultured material from damp rocks. It was earlier described in the same habitats in GSMNP (JOHANSEN et al. 2004, 2007). The genus Chroococcus is generally distributed in lentic freshwater and brackish habitats in shallow waters among macrophytes, as well as in aerial habitats such as wet rocks (JoHN et al. 2002).

\section{Nostoc epilithicum Ercegović (Fig. 3)}

Site: GSM 4D, damp rocks.

Colony spherical, dull blue-green, up to 6 $\mathrm{mm}$ in diameter. Trichomes loosely entangled in mucilage, 5.5-6 $\mu \mathrm{m}$ in diameter. Mucilage unlamellated, structureless, colorless, but with a firm outer layer. Cells compressed spherical, usually shorter to sometimes longer than broad, with homogenous cell contents, dull blue-green, 5-6.5 $\mu \mathrm{m}$ long. Heterocytes spherical, pale yellowish in color, $6 \mu \mathrm{m}$ in diameter. Akinetes not observed.
This Nostoc was originally described from wet rocks in Croatia. It is possible it has been seen previously in the Great Smoky Mountains, but was likely described under the epithet Nostoc commune $\mathrm{VAUCHER}$.

\section{Symplocastrum friesii AgARdH (Fig. 4)}

Site: GSM 2C, soil.

Colony consisting of scattered filaments, not forming a conspicuous mat. Filaments with 1-3 trichomes, in a firm, thick mucilaginous sheath. Sheath lamellate, becoming thinner towards apices of trichomes, open, up to $14 \mu \mathrm{m}$ in diameter. Trichomes slightly to indistinctly constricted at the crosswalls, which are thin and indistinct, $4 \mu \mathrm{m}$ in diameter. Cells coarsely granular throughout, blue-green, 5-10 $\mu \mathrm{m}$ long. End cells conical, rounded, slightly longer than other cells, often more yellowish in color than other cells, less granular than other cells.

This species is characterized as a typical soil species (GEITLER 1932), which grows on wet soils. KomÁReK \& AnAgnostidis (2005) also note that $S$. friesii is both a subaerophytic and terrestrial species, distributed in temperate regions, and probably cosmopolitan.

\section{Chlorophyceae}

Bracteacoccus medionucleatus BISCHOFF et Bold (Fig. 5)

Site: GSM 5E; soil.

Colony on agar not mucilaginous, breaking up easily into single cells. Cells spherical, uninucleate when young, multinucleate when a mature zonoblast, with thin, smooth cell walls, 15-35 $\mu \mathrm{m}$ wide. Chloroplasts plate-like, numerous, located at the surface of the cell, sometimes in the cell interior, 3-4 $\mu \mathrm{m}$ in diameter. Zoospores unobserved.

This species has been found in prairies and undisturbed territories in Texas (USA) (ANDREYEVA 1998). B. medionucleatus is also very common in Ukraine (forest-steppe, Ukrainian Polesie, Ukrainian Carpathian Mountains, and Krym Mountains; see Kostikov et al. 2001).

Bracteacoccus minor (Chodat) Petrová (Fig. 6)

Sites: GSM 1B, GSM 2C, GSM 5F; soil and damp rocks.

Cells forming aggregates on agar, spherical, uninucleate when young, multinucleate when a 
mature zonoblast, with thin, smooth cell walls 5-25 $\mu \mathrm{m}$ wide. Chloroplasts thick discoid plates, numerous, located at the surface and filling the cell interior, 2-4 $\mu \mathrm{m}$ in diameter. Zoospores unobserved.

This is a very common alga in various soil and subaerophytic habitats within the park. This species has been characterized as the most common soil algae (ANDREYEVA 1998) and dominant in soil algocenoses in the forest of the former USSR (Aleksahina \& Shtina 1984). Kostikov et al. (2001) found this taxon in foreststeppe, steppe, Ukrainian Polesie, Ukrainian Carpathian Mountains, and Krym Mountains. EtTL \& GÄRTNER (1995) also characterized $B$. minor as cosmopolitan in soils. This species was found as an aerophytic alga on tree bark in Japan.

\section{Chlorolobion lunulatum Hindák (Fig. 7)}

Site: GSM 5F; soil.

Cells very elongate, isopolar, slightly to clearly lunate, sometimes attenuated at the apices, attached at one end by a small mucilage pad, 10 $\mu \mathrm{m}$ long, 2-4 $\mu \mathrm{m}$ wide. Chloroplast an elongated band, without a pyrenoid. Autospores not observed in our material.

This taxon was found in a single soil sample along Trillium Gap Trail. C. lunulatum is widely distributed in mountain soils in Slovakia, Russia, Tajikistan (ANDREYEVA 1998), the Czech Republic (EtTL \& GÄrTner 1995), and the Ukraine (Kostikov et al. 2001).

\section{Chloromonas clathrata KorschiKov in PASCHER} (Fig. 8)

Site: GSM 5C; soil.

Cells oval, with rounded papilla, 13-14 $\mu \mathrm{m}$ long, $6-10 \mu \mathrm{m}$ wide. Flagella arise from the papilla, about equal to the cell length. Chloroplast parietal, reticulate, filling the cell. Stigma anterior, elongated, reddish, large. Palmelloid stages and zygotes not observed.

C. clathrata has been found in polluted pools and channels, in dry soils of bogs in Latvia and Ukraine (DeDUSENKo-ShChEGOLEVA et al. 1959), and in eutrophic ponds (EтTL 1983). Our populations were in soil under Rhododendron, a very different habitat than those reported for this species. The morphology of our specimens were a good fit for the species, but subsequent molecular characterization of populations from polluted and eutrophic waters and soils of the Great Smoky Mountains may demonstrate the presence of



Figs 1-7. Terrestrial algae of the Great Smoky Mountains National Park, USA (GSMNP): (1) Chroococcus helveticus, single cell; (2) Chroococcus helveticus, dividing cell; (3) Nostoc epilithicum; (4) Symplocastrum friesii; (5) Bracteacoccus medionucleatus; (6) Bracteacoccus minor; (7) Chlorolobion lunulatum. Scale bar $10 \mu \mathrm{m}$.

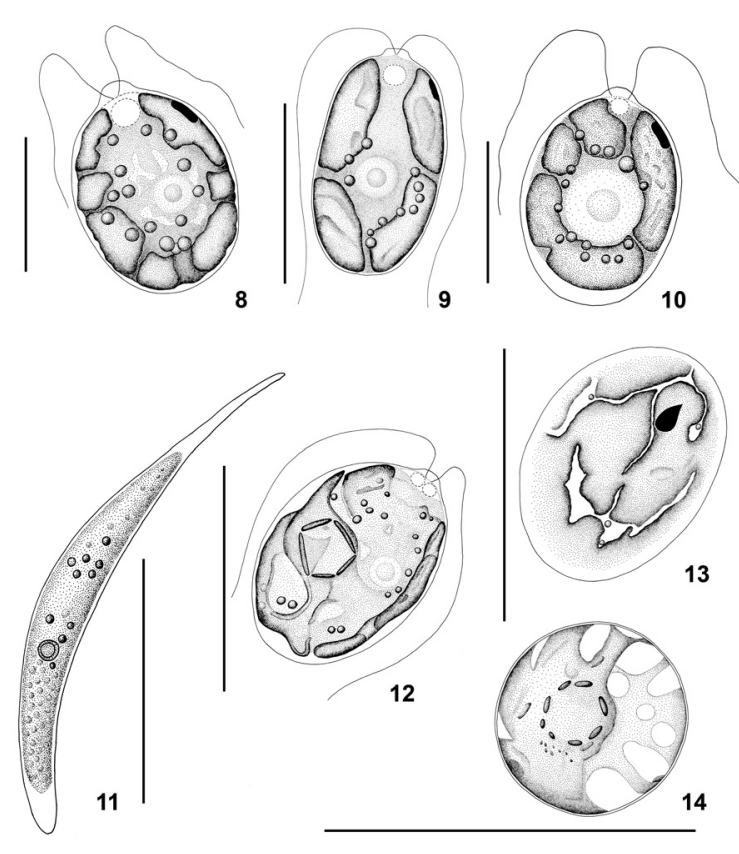

Figs 8-14. Terrestrial algae of the GSMNP: (8) Chloromonas clathrata; (9) Chloromonas mirabilis; (10) Chloromonas palmelloides; (11) Keratococcus rhaphidiodes; (12) Lobochlamys cf. culleus, median view; (13) Lobochlamys cf. culleus, surface view; (14) Neospongiococcum commatiforme. Scale bar $10 \mu \mathrm{m}$. 
cryptic species within this genus.

\section{Chloromonas mirabilis KoRSCHIKOV in PASCHER}

\section{(Fig. 9)}

Site: GSM 2E; soil.

Cells ellipsoid, with flattened papilla, with oil droplets in the cytoplasm, 11-12 $\mu \mathrm{m}$ long, 6-8 $\mu \mathrm{m}$ wide. Chloroplast parietal, reticulate, filling the cell. Stigma anterior, small. Palmelloid stages observed growing as a thin mat on the side of the culture tube. Zygotes not observed.

Our specimens were placed in this taxon due to the distinctive nature of the papilla and structure of the chloroplast. They did not fit either the nominate variety or $C$. mirabilis var. minor (BelCher) GerlofF et EtTL, being smaller than normal for the nominate variety and having the stigma more anterior in position than in var. minor. This species is planktonic in lakes in the former USSR, Sweden, Austria, and the Czech Republic (ETTL 1983) and in soil in the Ukrainian Carpathian Mountains (Kostikov et al. 2001). We suspect the soil forms in the USA and Ukraine may represent a separate and new species, but have insufficient evidence at this time to describe it as such.

\section{Chloromonas palmelloides BroAdy (Fig. 10)}

Site: GSM 5F; soil.

Cells oval, with small rounded papilla, $13 \mu \mathrm{m}$ long, $6 \mu \mathrm{m}$ wide. Flagella arising from the papilla, about equal to the cell length. Chloroplast parietal, with slits developing in the chloroplast but not anastomosing to form a reticulate surface, in median view appearing dissected. Nucleus large, central. Stigma anterior, tear-shaped, reddish, intermediate in size. Often in palmelloid stages. Zygotes not observed.

This species was found in soil samples from Signy Island and South Orkney Island (Antarctic) (EтtL 1983). Kostikov et al. (2001) found this taxon in the Ukrainian Carpathian Mountains.

\section{Keratococcus rhaphidioides (HANSGIRG) PASCHER (Fig. 11)}

Site: GSM 3A; soil.

Cells spindle-shaped, often bent irregularly or twisted at the ends, which come to a sharp point, attached to substratum by a stipe at one end, 13$29 \mu \mathrm{m}$ long, $2-3 \mu \mathrm{m}$ wide. Chloroplast solitary, parietal, filling all parts of the cell except apices, with a single pyrenoid.

This taxon has been previously found growing on wet rocks and tree bark in Central Europe (ANDREYEVA 1998).

Lobochlamys cf. culleus (ETTL) Pröschold, Marin, Schlösser et Melkonian (Figs 12, 13)

Site: GSM 2H; soil, bark, and rock.

Cells oval, with anterior end slightly pointed, with papilla, 10-13 $\mu \mathrm{m}$ long, 4-8 $\mu \mathrm{m}$ wide, surrounded by thin mucilage layer. Flagella arise from a papilla which is rounded or at times has an apical saddle-like depression, equal or slightly shorter than cell length. Chloroplast cup-shaped, with incisions, becoming dissected, becoming obscured by granules in scenscent cultures. Stigma anterior, teardrop shaped, reddish, $1.5 \mu \mathrm{m}$ long. Pyrenoid eccentric, mostly solitary, but sometimes in pairs, in thickened part of the chloroplast, covered by a starch sheath composed of numerous starch grains, with diameter 2-3 $\mu \mathrm{m}$. Nucleus large, $2-4 \mu \mathrm{m}$ in diameter. Two contractile vacuoles usually evident. In palmelloid stage the cells are surrounded by mucilage. Mucilage membrane thick. Zygotes not observed.

Our strains differ from the original description (EтTL 1965) in several particulars. The stigma is tear-drop shaped rather than elliptical, cells may contain two pyrenoids, the papilla has a saddle-shaped depression, and our cells were larger than the original populations. EтTL (1965, 1983) reported cells 7-11 $\mu \mathrm{m}$ long, 3-6 $\mu \mathrm{m}$ wide. Given that Ettl described the species from the plankton of a small lake in Bohemia, we strongly suspect that our taxon represents a new species. PRÖsCHOLD et al. (2001) conducted phylogenetic analysis based on sequence of the nuclearencoded SSU rRNA genes of Chlamydomonas sensu lato. They demonstrated the polyphyly of Chlamydomonas and began the revisionary taxonomic work necessary to characterize monophyletic genera. They erected Lobochlamys to include C. culleus EtTL and C. segnis EтtL. Our taxon shares the generic features of Lobochlamys and is somewhat similar to L. culleus. PRÖSCHOLD et al. (2001) emended the description of EтTL (1965) and reported a much greater range in size (10-18 $\mu \mathrm{m}$ long, 5-15 $\mu \mathrm{m}$ wide). We agree with the description of Lobochlamys, but question the identity of their strains of L. culleus with the original planktonic species described by ETTL (1965). We chose not to describe our populations as a new species at this time because molecular data, if available, might clarify the position of our strain with respect to the other sequenced strains. 
This work is planned for a future publication.

Neospongiococcum commatiforme DEASON (Fig. 14)

Site: GSM 5E; soil.

Cells rounded when young, as small as $5 \mu \mathrm{m}$ in diameter, becoming elongated and egg-shaped when mature, up to $28 \mu \mathrm{m}$ long, up to $20 \mu \mathrm{m}$ wide. In young cells chloroplast hollow, spherical, lobed, in mature cells spongy, filling the cell. Pyrenoid round, with a continuous starch sheath, relatively large, 4-5 $\mu \mathrm{m}$ wide. Zoospores naked, elongated, with an anterior stigma.

This taxon was described from soils in a rose garden in Memphis, Tennessee (DEAson \& HERNDON 1989), and our specimens are a very close fit to the original material. Observed in GSMNP in sandy soil by the Laurel Falls Trail. ETTL (1983) reported that this algae was also isolated from a bog soil in Elkhart, Indiana (USA).

\section{Trebouxiophyceae}

\section{Chlorella ellipsoidea Gerneck (Fig. 15)}

Sites: GSM 2A, 2B; soil.

Cells ellipsoidal, 4-10 $\mu \mathrm{m}$ long, 3.5-7 $\mu \mathrm{m}$ wide. Cell wall thick. Chloroplast parietal, lobed, containing a single large spherical or ellipsoid pyrenoid in the central part.

This taxon was widespread in soils, tree bark, and wet rock surfaces. During previous investigations $C$. ellipsoidea has been found in small ponds, in sand, on tree bark and in lichens (ANDREYeVA 1998; EtTl \& GärTNER 1995).

\section{Chlorella vulgaris BEIJERINCK (Fig. 17)}

Sites: GSM 1B, GSM 2G; soil, rock.

Cells spherical, 3-7 $\mu \mathrm{m}$ in diameter. Cell wall thin. Chloroplast cup-like or band-shaped, occuping $1 / 2-3 / 4$ of cell periphery, asymmetrical, with pyrenoid usually situated in the central part of the chloroplast.

This taxon was widespread in soils, tree bark, and wet rock surfaces. The pure culture was found as film on a wet green stone, lying on a road. This algae is known as a dominant in forests of the former USSR (Aleksahina \& Shtina 1984), and is considered to be cosmopolitan (ANDREYEVA 1998). C. vulgaris is widely distributed in soil and subaerial habitats, and likely encompasses a number of cryptic species.

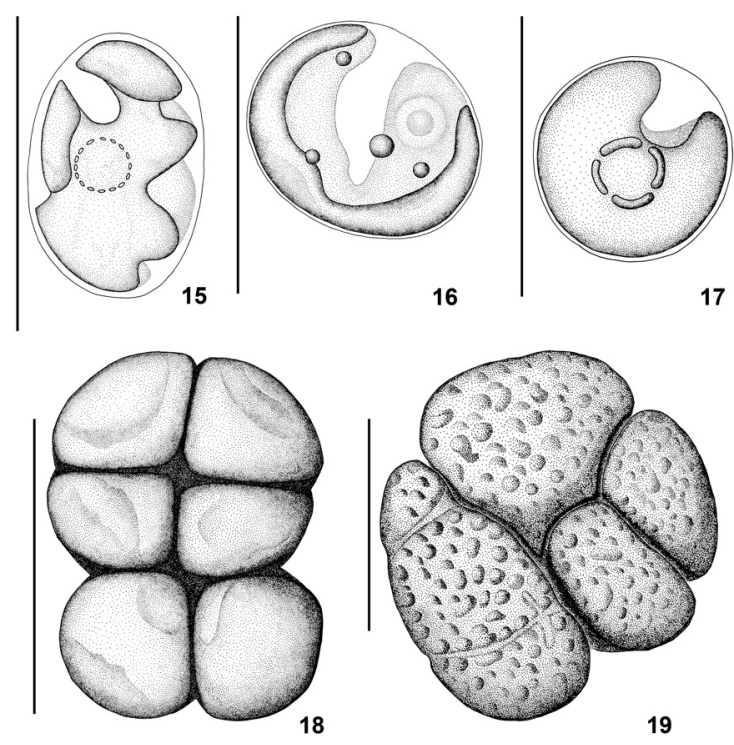

Figs 15-19. Terrestrial algae of the GSMNP: (15) Chlorella ellipsoidea; (16) Elliptochloris reniformis; (17) Chlorella vulgaris; (18) Chlorosarcina cf. elegans; (19) Chlorosarcina cf. rivulare. Scale bar $10 \mu \mathrm{m}$.

\section{Chlorosarcina cf. elegans GeRneK (Fig. 18)}

Site: GSM 2D; soil.

Cells in cubical packets, 4-6 $\mu \mathrm{m}$ wide. Chloroplast solitary, cup-shaped to massive, without pyrenoid. Starch grains evident in cell cytoplasm. Zoospores unobserved.

This Chlorosarcina fits the vegetative stages of C. elegans (ANDREYEVA 1998), but without zoospores we are unsure of its identification.

\section{Chlorosarcina ef. rivularis PANKow et MölleR} (Fig. 19)

Site: GSM 1A; soil, rock.

Colonies mucilaginous. Sheath colorless, unlamellated, soft. Cells in cubical packets, evenly dispersed in structureless mucilage, $6-8 \mu \mathrm{m}$ wide. Chloroplast single, cup-shaped, or completely filling the cell cavity, without pyrenoid, appearing finely granular. Zoospores unobserved.

This Chlorosarcina has the appearance of C. elegans, but without zoospores we are unsure of its identification.

\section{Choricystis chodatii (JAAG) FotT (Fig. 20)}

Sites: GSM 1C, GSM 2D; soil, rock.

Cells not embedded in mucilage, ellipsoid or egg-shaped, often connected in filaments of two or more cells, $7-8 \mu \mathrm{m}$ long, $3 \mu \mathrm{m}$ wide. Cell wall thin. Chloroplast cup-shaped, filling about half the cell.

This alga has been reported from humid 
soils and in plankton in Switzerland and Argentina (AndReYeva 1998) as well as from Antarctic soils (CAVACINI 2001).

\section{Choricystis minor (SKUJA) Fotт (Fig. 21)}

Sites: GSM 2A, GSM 5B, GSM 5G; soil, rock. Cells not embedded in mucilage, oval or rounded, $4 \mu \mathrm{m}$ long, $2 \mu \mathrm{m}$ wide. Chloroplast a parietal band, without pyrenoid. Cytoplasm granular.

ETTL \& GÄRTNER (1995) characterized this taxon as aerophilic on tree bark and humid soil. It was reported in forest-steppe communities in Ukraine (KostiKov et al. 2001).

\section{Dictyochloropsis reticulata (TSCHERMAK-WOESS) TSCHERMAK-WoEss (Fig. 22)}

Site: GSM 1D; soil.

Cells spherical, up to $15 \mu \mathrm{m}$ in diameter when young, up to $20 \mu \mathrm{m}$ in older cultures. Chloroplast single, parietal lobed after division, fragmenting into many filaments which form a reticulate mesh which surrounds the central cytoplasm containing the nucleus. Nucleus solitary, large, central. Sporangial cells producing numerous zoospores or aplanospores, which are easily visible inside the cell. Zoospores naked, tear-drop shape, with bluntly pointed anterior end, astigmatic, released in a mucous envelope, rapidly ceasing movement and rounding up immediately after that, $4-5 \mu \mathrm{m}$ wide. Autospores larger than zoospores.

This alga was found free-living in oldgrowth forest soil on the trail near Chimneys Picnic Ground. The alga has been reported to live freely and as a phycobiont of lichens (EтTL \& GäRTNER 1995; ANDREYEVA 1998). Although only found in one site, we expect this alga to be more broadly distributed in GSMNP as it is common in wooded ecosystems with mellow, rich organic soil, and has been observed in waterfall spray zones in other areas in the park.

\section{Dictyochloropsis splendida GeITLER (Fig. 23)}

Site: GSM 5F; soil.

Cells spherical, ellipsoidal when young, enclosed in a slime envelope when mature, uninucleate, 23-35 $\mu \mathrm{m}$ in diameter. Chloroplast fragmenting into many filaments which form a reticulate mesh, obscured by numerous starch grains, forming many layers of plastid which extend in to the center of the cell. Oil droplets conspicuous in young cells. Nucleus large, easily visible. Zoospores astigmatic, widely ellipsoidal, $8-12 \mu \mathrm{m}$ in length, up to $4 \mu \mathrm{m}$ wide.
Our specimens were free-living populations in soils of old growth maple forest near Laurel Falls. The zoospores of our culture were larger than ranges given in the original diagnosis (6-8 $\times 2-4 \mu \mathrm{m})$. This may represent a new species, but the culture was lost and we are unwilling at this time to describe a new species based on the evidence at hand. Our taxon is superficially similar to Dictyochloris pulchra DEASON et HERNDON, described for the first time from the GSMNP (DEASON \& HERNDON 1989), particularly with regard to the size and form of the zoospores, which were elongated in our material. It differs from that taxon by being uninucleate and lacking the posterior stigma.

D. splendida is a subaerial alga that can become lichenized (EtTL \& GÄrtner 1995; AndREyeVA 1998).

\section{Elliptochloris reniformis (S. WatANABE) EtTL et GärTNER (Fig. 16)}

Site: GSM 5G; soil.

Cells reniform when young, becoming ellipsoidal or rounded, 4-10 $\mu \mathrm{m}$ long, 2-5 $\mu \mathrm{m}$ wide. Chloroplast parietal, cup-shaped, becoming lobed, without a pyrenoid. Cytoplasm with numerous oil droplets. Autospores numerous, released by the rupture of the parent envelope.

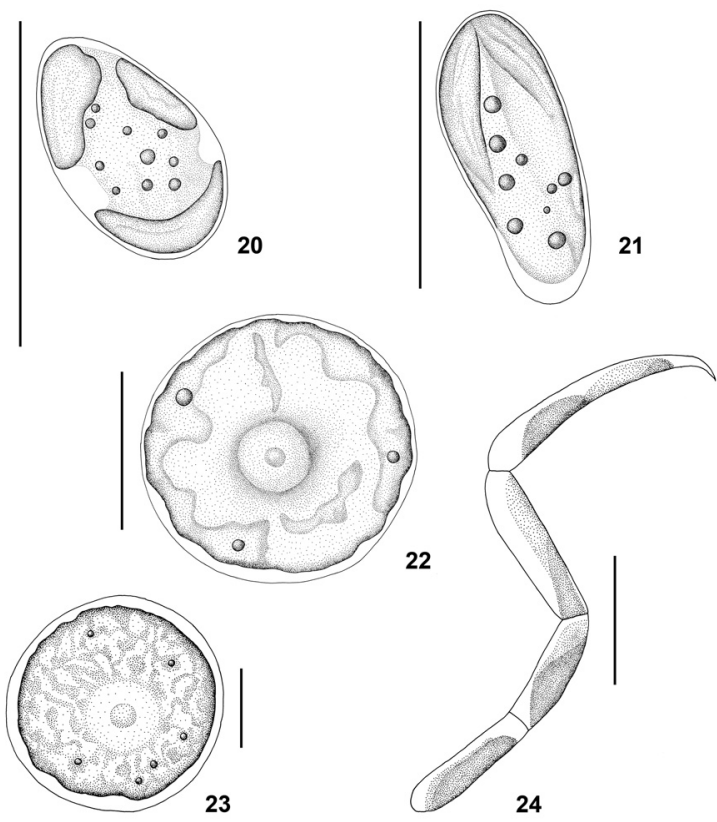

Figs 20-24. Terrestrial algae of the GSMNP: (20) Choricystis chodatii; (21) Choricystis minor; (22) Dictyochloropsis reticulata; (23) Dictyochloropsis splendida; (24) Raphidonema sempervirens. Scale bar $10 \mu \mathrm{m}$. 
This taxon was seen in a single old forest soil in the GSMNP. It has been found in forest and yard soils in Japan (ANDREYEVA 1998). It was formerly known as Chlorella reniformis S. WaTANABE.

Myrmecia biatorellae (TSCHERMAK-Woess et Plessl) J.B. Petersen (Fig. 25)

Site: GSM 2H; soil, bark.

Cells clustered in groups, spherical when young, becoming elongated and egg-shaped as they mature, 3-13 $\mu \mathrm{m}$ wide. Chloroplast parietal, filling the cell but developing splits, without a pyrenoid. Zoospores not observed in our material.

$M$. biatorellae is a widely distributed species reported from soils, tree bark, and in lichens (ETTL \& GÄRTNER 1995). It was found in soils, on rocks, and on tree bark in the Great Smoky Mountains National Park.

\section{Myrmecia bisecta ReISIGL (Fig. 26)}

Site: GSM 2D; soil.

Cells spherical, 6-12 $\mu \mathrm{m}$ wide. Chloroplast parietal and cup shaped in young cells, becoming partially divided into two unequal hemispheres that remain connected in mature cells. Sporangia up to $13 \mu \mathrm{m}$ wide.

This taxon was common in soils of old and young forests in the GSMNP, and was reported from dry mossy rocks in the park by GoMEz et al. (2003). M. bisecta is a soil alga with world-wide distribution. It has been reported from widely divergent climate regimes, including the Central Alps, forests and steppes of the republics of the former Soviet Union (ANDREYEVA 1998), in many regions in Ukraine (KostiKov et al. 2001), and among humid mosses and soils of Signy Island, Antarctica (ETTL \& GäRTNER 1995).

\section{Myrmecia incisa ReISIGL (Fig. 27)}

Sites: GSM 2A, GSM 2E, GSM 5C; soil.

Cells solitary, spherical, with a thin cell wall, up to $13 \mu \mathrm{m}$. Chloroplast parietal, divided into two or three lobes, without pyrenoid. Nucleus centrally placed or eccentric, with a distinct nucleolus. Zoospores not observed in our material.

This taxon is common and widely distributed in soils. It has been reported from soils of the Central Alps, Russia, and the desert of Baja California, Mexico (AndReyeva 1998; EtTL \& GÄRTNER 1995; FLECHTNER et al. 1998). It is very likely that cryptic diversity would be found if sequencing of populations from diverse climatic regimes were conducted.

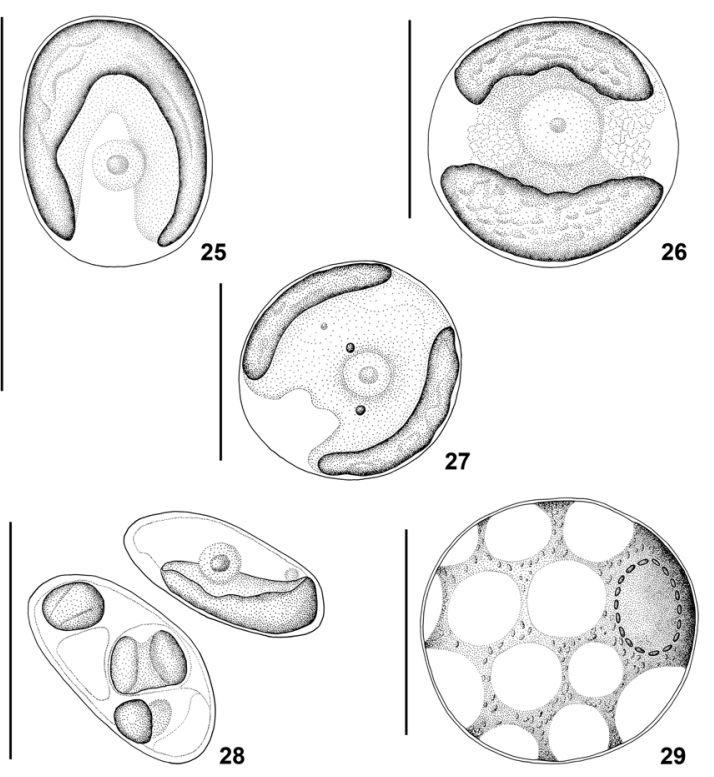

Figs 25-29. Terrestrial algae of the GSMNP: (25) Myrmecia biatorellae; (26) Myrmecia bisecta; (27) Myrmecia incisa; (28) Pseudococcomyxa simplex; (29) Spongiochloris minor. Scale bar $10 \mu \mathrm{m}$.

\section{Pseudococcomyxa simplex (MaInx) Fott (Fig.} 28)

Sites: GSM 2A, GSM 2C, GSM2D, GSM 4A; soil, rock.

Cells not embedded in mucilage, elongate, asymmetrical, rounded at the apex, narrowed towards the end attached to the substrate, attached by a small mucilage pad, $8-9 \mu \mathrm{m}$ long, $2 \mu \mathrm{m}$ wide. Chloroplast an elongate parietal band, without pyrenoid. Autospores 2-4 per cell.

P. simplex is a very widely distributed species (ANDREYEVA 1998). It has been reported from the Carpathian Mountains, in acidified soils of Italy, on tree bark in Japan, in the Ukrainian forest-steppe ecoregion, and in Antarctica (ETTL \& GärTNER 1995; KostiKov et al. 2001). It is probably more widely distributed in North America, but has likely been confused with Coccomyxa, to which it is similar. Pseudococcomyxa differs in the lack of mucilage, solitary growth habit, and presence of the mucilage pad. This taxon was repeatedly collected from soils and wet rocks in the park.

Raphidonema sempervirens CHОDAT (Fig. 24) Site: GSM 4B; rock.

Colonies on agar similar in appearance to colonies of Stichococcus, but softer, light green, $3 \mathrm{~mm}$ across after one month of growth. Filaments short, most commonly of two cells, but up to 10 cells 
in length, variously bent or spiral, unconstricted at the crosswalls immediately after division, becoming constricted before breakage into smaller filaments, attached to substrate at one end, which is more pointed, with other end bluntly rounded, thick. Cells $2 \mu \mathrm{m}$ wide, 10-20 $\mu \mathrm{m}$ long. Chloroplast solitary, without pyrenoid.

Taxonomy of this species is somewhat controversial. Some authors think that Rhaphidonema sempervirens CHODAT should be placed in Koliella sempervirens (СНODAT) HINDÁK (Hindák 1963; Moshrova \& Gollerbach 1986). HINDÁK (1963) based his transfer on the fact that Rhaphidonema forms multicelled filaments, while Koliella is one-celled or at most forms two-celled filaments. Rhaphidonema is characterized as a cryophilic genus; Koliella grows on humid soils (MoshKova \& Gollerbach 1986) or associated with snow and ice. ETTL \& GärTNER (1995) and Kostikov et al. (2001) reject the transfer into Koliella. Since our specimens were multicelled filaments, we prefer to place them in Raphidonema. The question of whether or not Koliella is a clade of species separate from the Raphidonema clade will likely not be resolved until molecular work is completed.

\section{Spongiochloris minor Chantanachat \& Bold} (Fig. 29)

Site: GSM 1B; rock.

Cells spherical, with thin cell walls, 10-13 $\mu \mathrm{m}$ wide. Chloroplast spongy, filling the cell. Pyrenoid large, with a starch sheath composed of many grains, $4 \mu \mathrm{m}$ wide. Autospores and zoospores not observed.

This alga is typical of desert and mountain soils in the USA, Russia, Turkey, Tajikistan, and Ukraine (ANDREYEVA 1998; ETTL \& GÄRTNER 1995; Kostikov et al. 2001).

\section{Stichococcus bacillaris NÄGELI (Fig. 30)}

Sites: GSM 2A, GSM 2D, GSM 2E, GSM 2F, GSM 3A, GSM 3B, GSM 4D, GSM 5A, GSM 5D, GSM 5F; soil, rock.

Cells solitary or in short easily broken filaments of $2-8$ cells, cylindrical, with rounded ends, $4-8 \mu \mathrm{m}$ long, 2-3 $\mu \mathrm{m}$ wide. Chloroplast parietal, with smooth margins.

S. bacillaris has been reported from humid soils, on brick and wooden walls, on semi-rotten wood, and sometimes in water (Moshrova \& GollerbaCh 1986). This is considered by many to be one of the most cosmopolitan algae, occurring from Antarctic climates to the deserts of North America (EtTl \& GÄRTNER 1995; FleChtNER et al. 1998; CAVACINI 2001; KostiKov et al. 2001; JoHN 2003). It is widely distributed in the park (Gomez et al. 2003). In two samples, specimens identified by size to be Stichococcus bacillaris but with a bent form were observed. We are not sure whether or not this character represents genetic separation or is just an ecophenotype.

\section{Stichococcus minor NÄGELI (Fig. 31)}

Sites: GSM 1C, GSM 3B, GSM 5G; soil.

Cells solitary, sometimes in very short filaments (2-4 cells), cylindrical, with rounded ends, $4-5 \mu \mathrm{m}$ long, 1-3 $\mu \mathrm{m}$ wide. Chloroplast bright-green with smooth margin, filling $1 / 3-1 / 2$ of the cell. Cytoplasm with small granules, which increase in number in old cells, with oil droplets near poles of largest cells.

This alga is very common in soils, on bark, and on rocks (MoshKova \& Gollerbach 1986; Kostikov et al. 2001).

\section{Stichococcus minutus Grintzesco \& Péterfi (Fig. 32)}

Sites: GSM 1B, GSM 2D; soil, rock.

Cells solitary or in pairs, ellipsoidal to nearly spherical, $4-5 \mu \mathrm{m}$ long, $2-5 \mu \mathrm{m}$ wide. Chloroplast pale-green, disc-like.

This species was found in soils of immature maple forest in this study, but has been reported from epilithic habitats in the park as well (GoMEZ et al. 2003).

\section{Ulvophyceae}

\section{Fernandinella alpina CHODAT (Figs 33, 34)}

Site: GSM 2D; soil.

Colonies are of loosely aggregated cells in flat, planar single layer. Cells oval, egg-shaped, or teardrop shaped, with broadened end attached to the substrate, dividing in two planes, 4.5-10 $\mu \mathrm{m}$ wide. Chloroplast parietal, cup-shaped, with a pyrenoid. Zoospores reported to be quadriflagellate, not observed in our material. This alga is very common in the soils of Eurasia (EtTl \& GÄrTner 1995, AndReyeva 1998, KostiKov et al. 2001), but this represents the first report from the park (JoHANSEN et al. 2007).

Geminella terricola J. B. Petersen (Fig. 35) Site: GSM 2B; bark.

Cells egg-shaped, sometimes nearly round, 
mostly in pairs, also solitary, 6-8 $\mu \mathrm{m}$ long, 5-6 $\mu \mathrm{m}$ wide. Chloroplast parietal, cup shaped, with scalloped margins, light green in color. Pyrenoid solitary, in a thickened part of the chloroplast, 2 $\mu \mathrm{m}$ in diameter.

This alga is typical of humid soils (MosHKoVA \& GollerbaCh 1986). It has been reported from several regions: in soil in Denmark and the Alps, and on rocks in Antarctica (ETTL \& GÄRTNER 1995), in Ukrainian soils (KostiKov et al. 2001), and forest soils in the Ardenn of Belgium (HoFfmanN et al. 2007). This species was incorrectly reported as Interfilum paradoxum in JOHANSEN et al. (2007).

\section{Ulothrix variabilis KüTZING (Fig. 36)}

Site: GSM 3A; soil.

Filaments mostly short, strait or bent, with prominent $\mathrm{H}-$ shape pieces. Cells cylindrical, 8-14 $\mu \mathrm{m}$ long, 6-9 $\mu \mathrm{m}$ wide. End cells rounded. Pyrenoid single, containing numerous starch grains. Cytoplasm granular in old cultures, with a central nucleus.

Our strain was slightly larger than reported by other authors - cf. $4.5-7 \mu \mathrm{m}$ wide, $0.5-1.5(-2)$ times longer than wide in ETTL \& GÄRTNER 1995 and 5-7(8.4) $\mu \mathrm{m}$ wide, 0.5-(2)3 times longer than wide in Moshrova \& Gollerbach (1986). However, they corresponded well with the size dimensions in John et al. (2002). MoshKova \& Gollerbach (1986) describe this species with a large chloroplast and large pyrenoid while EттL \& GÄRTNER (1995) characterized the pyrenoid as a small. JoHn et al. (2002, p. 467) describe the alga as having a small plate-like chloroplast, covering just over half of the cell circumference, with one pyrenoid. The alga has a cosmopolitan distribution in stagnant and flowing waters and in soils.

\section{Klebsormidiophceae}

Klebsormidium flaccidum (KütZING) SILvA, Mattox et BlackWell (Fig. 37)

Sites: GSM 2D, GSM 2H, GSM 5A; soil, bark.

Filaments mostly long, rarely short. Cells cylindrical, practically without constrictions at the crosswalls, sometimes barrel-shaped, 9-10 $\mu \mathrm{m}$ long, 4-5 $\mu \mathrm{m}$ wide. Cell walls thin. Chloroplast parietal, bracelet-shaped, with smooth margins with a single pyrenoid ensheathed by many starch grains. Nucleus with nucleous clearly visible.

This alga was very common in many sites in the park. K. flaccidum is the most widely distributed and reported species of the genus Klebsormidium,


Figs 30-35. Terrestrial algae of the GSMNP: (30) Stichococcus bacillaris; (31) Stichococcus minor; (32) Stichococcus minutus; (33) Fernandinella alpina, round cell; (34) Fernandinella alpina, colony of eye-shaped cells; (35) Geminella terricola. Scale bar $10 \mu \mathrm{m}$.

and is consistently in subaerial habitats and soils (Moshrova \& Gollerbach 1986; ETTL \& GäRTNER 1995; LOKHORST 1996; JoHN et al. 2002).

\section{Zygnematophyceae}

Mesotaenium endlicherianum NÄGELI (Fig. 38) Site: GSM 3A; soil.

Cells embedded in structureless mucilage, ellipsoidal or cylindrical, mostly straight, but sometimes slightly curved, 15-27 $\mu \mathrm{m}$ long, $8 \mu \mathrm{m}$ wide. Chloroplast ribbon-like.

This taxon has been reported from the park before and is fairly common on wet rock surfaces. This is the first report from soil in the park.

\section{Mesotaenium macrococcum (KüTZING) RoY \& Bisset (Fig. 39)}

Site: GSM 3A; soil.

Cells embedded in structureless mucilage, cylindrical with broadly rounded ends, 16-20 $\mu \mathrm{m}$ long, $8-10 \mu \mathrm{m}$ wide. Chloroplast parietal, bracelet-shaped, with prominent pyrenoid. This taxon was reported from the GSMNP in previous investigations (FučíkovÁ et al. 2008; GoMEZ et al. 2003). The GSMNP populations are characterized by having cells corresponding to the minimum size range reported by other authors (РRESCOTT et 


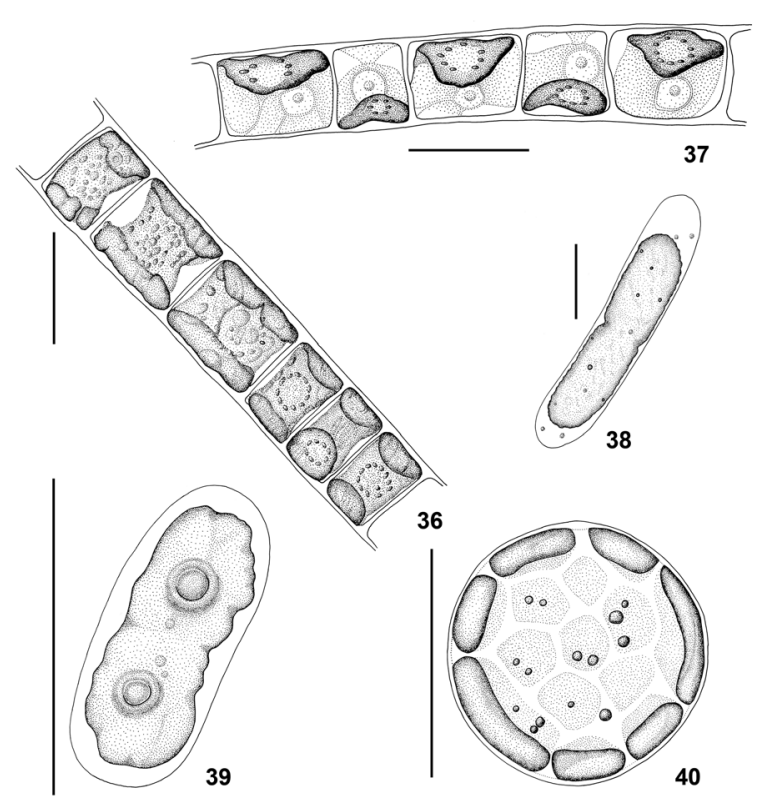

Figs 36-40. Terrestrial algae of the GSMNP: (36) Ulothrix variabilis; (37) Klebsormidium flaccidum; (38) Mesotaenium endlicherianum; (39) Mesotaenium macrococcum; (40) Botrydiopsis arhiza. Scale bar $10 \mu \mathrm{m}$.

al. 1972, EtTl \& GäRTNER 1995). This alga was found in a mineral soil in a dirt road at the start of Trillium Gap Trail.

\section{Tribophyta}

\section{Botrydiopsis arhiza BorzI (Fig. 40)}

Site: GSM 4C; rock.

Cells ellipsoidal when very young, compressed in close association, quickly becoming spherical, with markedly different sizes, uninucleate, with oil droplets, 5-36 $\mu \mathrm{m}$ in diameter. Chloroplasts numerous, plate-like, without pyrenoid.Zoospores unobserved.

This taxon is one of the dominant species in forest soils in the former USSR (ALEKSAHINA \& ShTINA 1984) and was also reported from ponds, peat bogs, on rocks and tree bark (DEDUSENKoShCHEGOLEVA \& Gollerbach 1962). It has a cosmopolitan distribution in soils of temperate and polar regions (ETTL \& GäRTNER 1995; CAVACINI 2001).

\section{Heterococcus sp. (Fig. 41)}

Site: GSM 2E, GSM 4C; soil, rock.

Colony bush-like, with filaments arising out of prostrate basal coccoid layer, obtaining a diameter of about $5 \mathrm{~mm}$ after 10 days of growth, developing at least some sparsely branched long filaments that grow horizontally out from the bushy center. Filaments short in vicinity of basal layer, becoming quite long, branched irregularly, with both primary and secondary branches, 3-4 $\mu \mathrm{m}$ wide in actively growing tips, becoming up to $7 \mu \mathrm{m}$ wide. Cells of filaments commonly with 2 plate-like plastids, but sometimes having 4 chloroplasts, with granules, with lipid droplets, 2-3 $\mu \mathrm{m}$ in diameter, 9-15 $\mu \mathrm{m}$ long. Enlarged coccoid cells forming in filamentous series in interior parts of filaments, sometimes developing thickened, brownish cell walls, up to $10 \mu \mathrm{m}$ in diameter. Chloroplasts mostly 2 per cell, becoming lobed, and sometimes dividing into 4 chloroplasts, without pyrenoid.

During this study, five strains of Heterococcus were isolated. These strains were very similar in morphology, but may represent multiple species in this problematic genus. This description is based on only one of the strains.

Xanthonema bristolianum (PASCHER) SiLva (Fig. 42)

Site: GSM 1A; soil.

Filaments short, easily broken. Cells cylindrical or slightly barrel-shaped, 9-12 $\mu \mathrm{m}$ long, 4-6 $\mu \mathrm{m}$ wide, with 4-12 disc-liked pyrenoids.

This alga has been reported from the park before on wet rocks (Gomez et al. 2003). It is commonly seen in soils (Dedusenko-ShCheGoleva \& Gollerbach 1962).

\section{Eustigmatophyta}

Eustigmatos magnus (Petersen) Hibberd (Fig. 43)

Site: GSM 2C; soil.

Cells 5-30 $\mu \mathrm{m}$ (mostly 6-12 $\mu \mathrm{m}$ ), spherical. Cell wall is thin. Chloroplast single but deeply lobed. Pyrenoid polyhedral. Cytoplasm containing many vesicles. The cells in our cultures are slightly smaller than reported elsewhere $(14-34 \mu \mathrm{m}$ in ETTL \& GÄRTNER 1995), although the overlap is high.

This taxon has been reported from wet rocks in the park previously (Gomez et al. 2003). It is one of the most widely distributed soil algae of temperate climates. It has been found in agricultural soils, meadows, forests, rocks, and on volcanic substrates (ETTL \& GÄrTner 1995; KostiKov et al. 2001; Mikhailiuk et al. 2001). 


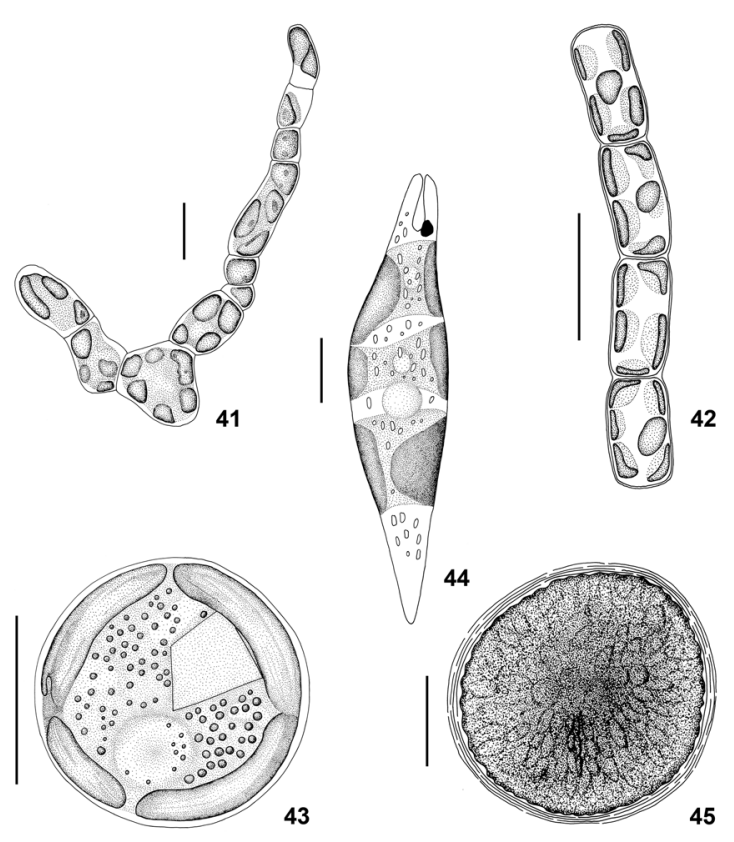

Figs 41-45. Terrestrial algae of the GSMNP: (41) Heterococcus sp.; (42) Xanthonema bristolianum; (43) Eustigmatos magnus; (44) Euglena mutabilis; (45) Rufusiella insignis. Scale bar $10 \mu \mathrm{m}$.

\section{Euglenophyta}

\section{Euglena mutabilis Schмітz (Fig. 44)}

Sites: GSM 2D, GSM 2H; soil.

Cells 70-80 $\mu \mathrm{m}$ long, $13-16 \mu \mathrm{m}$ wide, with $2-8$ ring-shaped chloroplasts, lacking an emergent flagellum.

This alga is wider than described by EтTL \& GÄrNER (1995) and JoHN et al. (2002), but corresponds to the populations observed by HofFMANN et al. (2007) in soil cultures.

\section{Dinophyta}

\section{Rufusiella insignis (HassaL) A. R. LOEblich} (Fig. 45)

Site: GSM 2H; soil.

Cells spherical, brown in colour, $30-40 \mu \mathrm{m}$ wide. Cell wall appearing gelatinous, thick, $2 \mu \mathrm{m}$ wide. Chloroplast granular in appearance. This taxon has been seen repeatedly in the park, but this represents the first observation from soil. The cells were observed in soil from beech-maple forest in a humid area on Baskins Creak Trail.

This alga is widely distributed in wet walls and seeps in the Great Smoky Mountains National Park (JohAnsen et al. 2007). It is considered the more correct name for what has often been reported as Gloeodinium montanum KLEBS.

\section{Discussion}

The soil algal flora of GSMNP has features typical of forest soil communities, such as the low diversity of Cyanobacteria and prevalence of unicellular coccoid algae in Chlorophyceae and Trebouxiophyceae. Such communities have been reported for forest soils in Russia (AleKsahina \& Shtina 1984), and Belgium (Hoffmann et al. 2007). The rarity of Cyanobacteria may be the result of low pH. Only one species of cyanobacteria, Symplocastrum friesii, was detected in soil.

Several of the taxa we found in the forest soils of the Great Smoky Mountains National Park were taxa that often are dominant in forest soils in other parts of the world, including: Chlorella vulgaris, Bracteacoccus minor, Stichococcus bacillaris, Stichococcus minor, Botrydiopsis arhiza, Eustigmatus magnus, and Hantzschia amphioxis (not illustrated in this paper). Presence of the genera Chlorella, Klebsormidium, and Xanthonema also indicated our flora was typical of forest soil algal floras.

HofFMANN et al. (2007) during their investigation of the algal flora from limed and unlimedacidic forest soils in theArdenne(Belgium) detected an absence of many taxa typical of forest algal floras, such as all Eustigmatophyceae, Chlorella species, and Stichococcus bacillaris. They postulated the absence of these algae was due to low $\mathrm{pH}$ and low nutrient concentrations. However, we found these taxa in acid soils $(\mathrm{pH}=3.8-5.8)$ of the park, indicating that their noteworthy absence in Ardenne may be due to other factors.

Rufusiella insignis is indicative of low $\mathrm{pH}$ and wet conditions, and is a common member of seep wall floras in the park (JoHANSEN et al. 2007). Euglena mutabilis often occurs in streams contaminated with acid mine drainage. The aquatic species Ulothrix variabilis has been reported from damp soils but is still noteworthy as all of our soils were in dry (albeit humid) areas distant from flowing and standing water. Another interesting characteristic of the soil algal flora of GSMNP is the presence of many species of Trebouxiophyceae (18 species in all), including 3 species of Myrmecia (M. bisecta, M. incisa, and M. biatorellae) and 2 species of Dictyochloropsis (D. reticulata, and D. splendida). These algae are known as phycobionts of many lichens. Their presence as free-living taxa may be connected with the abundance of lichens on soil and tree bark 
in the park. Hoffmann et al. (2007) also detected many representatives of Trebouxiophyceae in limed and unlimed forest soils in Ardenne.

Aerial algae isolated only from rock surfaces included Chroococcus helveticus, Nostoc epilithicum, Spongiochloris minor, Raphidonema sempervirens, and Botrydiopsis arhiza. Of these, only $R$. sempervirens was unusual for a moderate climate. During previous investigations, this taxon was found in the Antarctic and Iceland and characterized as a cryophilic alga. It is possible, that several ecotypes of this species exist.

Only one alga was found on tree bark, Geminella terricola. It was detected from wet rocks in the GSMNP in a previous study (GoMEZ et al. 2003), and isolating this algae from bark is also interesting in connection with the ecology of this species which previously is reported only from soils (ETTL \& GÄRTNER 1995).

Some species were found both in soil and in aerial habitats. These are mostly very widely distributed algae including: Chlorella vulgaris, Pseudococcomyxa simplex, Klebsormidium flaccidum, Stichococcus bacillaris, Bracteacoccus minor, Myrmecia biatorellae, and Choricystis chodatii.

With the publication of this paper, the algal flora of the Great Smoky Mountains National Park now has 1019 reported taxa. We consider the soil algae to still be poorly studied. Many taxa we report were very limited in their distribution, and we suspect with a more intensive sampling effort we would find many more taxa. The subaerial habitats of the park have received much more study (GomeZ et al. 2003; JoHANSEN et al. 2007; FučíkovÁ et al. 2008), and have been the source of many algal species records. Not only should forest soils receive study, but we should examine the soils of more open habitats such as the grassy meadows of Cades Cove, Cataloochee Valley, Andrews Bald, and Gregory Bald. The aerial algae growing on trees and dry rock faces are also very understudied. Work on the algal flora of the park will likely continue for many years before it becomes difficult to obtain new species records.

\section{Dedication}

This work is dedicated to the memory of Liliya S. Khaybullina, who tragically died during the middle of this project. She was an esteemed friend and colleague, and a promising young scientist, and she will be sorely missed.

\section{Acknowledgements}

We would like to thank Andrey Gontcharov, Tatyana Mikhailyuk, Edvard Demchenko, Thomas Pröschold and Karolina Fučíková for help in algae identification. The project was supported by the Russian Federal Agency of Grants and Innovations, grants numbers 02.444.11.7287 and 02.444.11.7289.

\section{References}

Aleksahina, T.I. \& Shtina, E.A. (1984): Terrestrial algae of forest biogeocoenoses (Pochvennye vodorosli lesnych biogeotsenozov). - 147 pp., Nauka, Moskva. [in Russian]

Anagnostidis, K. \& KomÁreK, J. (1985): Modern approach to the classification system of the Cyanophytes 1:Introduction.-Arch. Hydrobiol./ Algological Studies 38/39: 291-302.

Anagnostidis, K. \& KomÁreK, J. (1988): Modern approach to the classification system of the Cyanophytes 3: Oscillatoriales. - Arch. Hydrobiol./Algological Studies 50/53: 327472.

Anagnostidis, K. \& KomÁrek, J. (1990): Modern approach to the classification system of the Cyanophytes 5: Stigonematales. - Arch. Hydrobiol./Algological Studies 86: 1-74.

ANDREYeVA, V.M. (1998): Terrestrial and aerophilic green algae - Chlorophyta: Tetrasporales, Chlorococcales, Chlorosarcinales (Pochvennye i aerofil'nye zelenye vodorosli - Chlorophyta: Tetrasporales, Chlorococcales, Chlorosarcinales). - 351 pp., Nauka, St. Petersburg. [in Russian]

Carmichael, W.W. (1986): Isolation, culture, and toxicity testing of toxic freshwater cyanobacteria (blue-green algae). - In: Shilov, V. (ed.): Fundamental research in homogenous catalysis 3. - pp.1249-1262, Gordon \& Breach, New York.

CAVAcin, P. (2001): Soil algae from northern Victoria Land (Antarctica). - Polar Biosci. 14: 45-60.

Deason, T.R. \& Herndon, W.R. (1989): Three new green coccoid zoospore-producing algae from the Great Smoky Mountains National Park, Tennessee, U.S.A. - Pl. Syst. Evol. 164: 123132.

Dedusenko-Shchegoleva, N.T. \& Gollerbach, M.M. (1962): Yellow green algae - Xanthophyta (Zheltozelenye vodorosli). - In: Gollerbach, M.M. (ed.): Identification guide to freshwater algae of the USSR. Vol. 5 (Opredelitel' presnovodnych vodoroslei SSSR. Vyp. 5). -272 pp., Akademiya Nauk SSSR Press, Moscow Leningrad. [in Russian].

Dedusenko-Shchegoleva, N.T., Matvienko, O.M. \& Shкorbatov, L.A. (1959) Chlorophyta: 
Volvocineae (Zelenye vodorosli - Klass vol'voksovye). - In: Gollerbach, M.M. (ed.): Identification guide to fresh-water algae of the USSR.Vol. 8 (Opredelitel' presnovodnych vodoroslei SSSR. Vyp. 8). -230 pp., Akademiya Nauk SSSR Press, Moscow - Leningrad. [in Russian].

Etть, H. (1965): Beitrag zur Kenntnis der Morphologie der Gattung Chlamydomonas EgRenBerg. Arch. Protistenk. 108: 271-430.

Etтl, H. (1978): Xanthophyceae I. - In: EтtL H., Gerloff J., Heynig H. (eds.): Süßwasserflora von Mitteleuropa, vol. 3.- 530 pp., Gustav Fischer Verlag, Stuttgart - New York.

Etru, H. (1983): Chlorophyta I. Phytomonadina. - In: Ettl H., Gerloff J., Heynig H., Mollenhauer D. (eds.): Süßwasserflora von Mitteleuropa, vol. 9.- 808 pp., Gustav Fischer Verlag, Stuttgart New York.

Ettl, H. \& GÄrtner, G. (1988): Chlorophyta II: Tetrasporales, Chlorococcales, Gloeodendrales. - In: Ettl H., Gerloff J., Heynig H., Mollenhauer D. (eds.): Süßwasserflora von Mitteleuropa, vol.10. - 436 pp., Gustav Fischer Verlag. Stuttgart - New York.

Ettl, H. \& Gärtner, G. (1995): Syllabus der Boden-, Luft- und Flechtenalgen. - 721 pp., Gustav Fischer Verlag, Stuttgart.

Flechtner, V.R.; Johansen, J.R.; Clark, W.H. (1998): Algal composition of microbiotic crusts from the Central Desert of Baja California, Mexico. - Great Basin Naturalist 58: 295-311.

Fučíková K., Hall J.D., Johansen J.R., \& Lowe R. (2008): Desmid flora of the Great Smoky Mountains National Park, USA. - Bibliotheca Phycologica 113: 1-59.

Geitler, L. (1932): Cyanophyceae von Europa. Reprint 1985. - 1196 pp., Koeltz Scientific Books, Koenigstein.

Gomez, S.R., Johansen J.R. \& Lowe, R.L. (2003): Epilithic aerial algae of Great Smoky Mountains National Park. - Biologia 58: 603-615.

HindáK, F. (1963): Systematik der Gattungen Koliella gen. nov. und Raphidonema LAGERH. - Nova Hedwigia 6: 95-125.

Hoffmann, L., Ector, R.L. \& Kostikov, I. (2007): Algal flora from limed and unlimed forest soils in the Ardenne (Belgium). - Syst. Geogr. P1. 77: 15-90.

Johansen, J.R., Lowe, R., Carty, S., Fučiková, K., Olsen, C.E., Fitzpatrick, M.H., Ress, J.A. \& FurEY, P.C. (2007): New algal species records for the Great Smoky Mountains National Park, with an annotated checklist of all reported algal taxa for the park. - Southeastern Naturalist 6 : 99-134.

Johansen, J.R., Lowe, R., Gomez, S.R., Kociolek, J.P. \& Makosky, S.A. (2004): New algal species records for the Great Smoky Mountains National Park, USA, with an annotated checklist of all reported algal species for the park. - Arch. Hydrobiol./Algological Studies 111: 17-44.

JoHn, D.M. (2003): Filamentous and plantlike green algae. - In: Wehr, J.D. \& SheAth R.G. (eds): Freshwater algae of North America. - 352 pp., Elsevier Science, San Diego.

John, D.M., Witton, B.A. \& Brook, A.J. (2002): The freshwater algal flora of the British Isles: an identification guide to freshwater and terrestrial algae. - 702 pp., Cambridge University Press, Cambridge.

KomÁrek, J. \& Anagnostidis, K. (1986): Modern approach to the classification system of the Cyanophytes, 2. Chroococcales. - Arch. Hydrobiol./Algological Studies 43: 157-226.

KomÁreK, J. \& AnAgnostidis, K. (1989): Modern approach to the classification system of the Cyanophytes, 4. Nostocales. - Arch. Hydrobiol./ Algological Studies 56: 247-345.

KomáreK, J. \& Anagnostidis, K. (1999): Cyanoprokaryota, 1. Chroococcales. - In: EtTL, H., Gärtner, G.,Heynig, H. \& Mollenhauer, D. (eds): Süßwasserflora von Mitteleuropa, vol. 19/1. - 548 pp., Gustav Fischer Verlag, Stuttgart - New York.

Komárek, J. \& Anagnostidis, K. (2005): Cyanoprokaryota, 2. Oscillatoriales. - In: BüDEL,B., Gärtner, Krienitz, L. \& Schlagerl, M. (eds.): Süßwasserflora von Mitteleuropa, vol. 19/2. 760 pp., Elsevier GmbH, München.

KomáreK, J. \& Fotт, B. (1983): Chlorophyceae (Grünalgen) Ordnung: Chlorococcales. In: Elster H.-J. \& Ohle, W. (eds.): Die Binnengewasser XVI.-1044 pp., Schweizerbart Verlag, Stuttgart.

Kostikov I.J, Romanenko, P.O., Demchenko, E.M., Darienko, T.M., MikhayluUK, T.I., RYbChnnskiy, O.V. \& Solonenko, A.M. (2001): Soil algae of Ukraine (Vodorosti gruntiv Ukrajiny). - 300 pp., Phytosotsiologichniy center, Kiev. [in Ukrainian]

LOKHORST, G.M.(1996): Comparative taxonomic studies on the genus Klebsormidium (Charophyceae) in Europe. - Cryptogamic Studies 5: 1-132.

Matvienko, O.M. \& Dogadina, T.V. (1978): Yellow green algae - Xanthophyta (Zheltozelenye vodorosli). - In: Gollerbach, M.M. (ed.) (Viznachnik prisnovodnych vodorostey URSR. Vyp. 10). - 512 pp., Naukova dumka, Kiev. [in Ukrainian]

Mikhailiuk, T.I., Tsarenko, P.M., Nevo, E. \& Wasser, S.P. (2001): To study of aerophytic eukaryotic algae of Israel. - Algologia 11: 371-390.

Moshkova, N.A. \& Gollerbach, M.M. (1986): Green algae 1. Chlorophyta: Ulotrichophyceae, Ulotrichales. - In: Gollerbach, M.M. (ed.): 
Identification guide to fresh-water algae of the USSR. Vol. 10 /1 (Opredelitel' presnovodnych vodoroslei SSSR. Vyp. 10/1). - 360 pp., Nauka Press, Leningrad. [in Russian]

Prescott, G.W., Croasdale, H.T. \& Vinyard, W.C. (1972): Desmidiales, Saccodermae, Mesotaeniaceae. - In: Rogerson, C.T. (ed.): North Americal Flora, vol. II/6. - 84 pp., The New York Botanical Garden, New York.

Pröschold, T., Marin,B., Schlosser, U.G.\&Melkonian, M. (2001): Molecular phylogeny and taxonomic revision of Chlamydomonas (Chlorophyta). I. Emendation of Chlamydomonas EHRENBERG and Chloromonas GoBI, and description of Oogamochlamys gen. nov and Lobochlamys gen. nov. - Protist 1524: 265-300.
Silva, H. (1949): Additions to the algae of the southeastern United States. - J. Elisha Mitchell Sci. Soc. 65: 90-109.

Starmach, K. (1968): Chrysophyta III, Xanthophyceae Różnowiciowe. - In: StaRmach, K. (ed.): Flora Slodkowodna Polski 7. - 395 pp., Panstwowe Wydawnictowo Naukowe, Warsawa - Krakov.

StARMACH, K. (1972): Chlorophyta III, Zielenice nitkowate. - In: STARMACH, K. \& SIEMIŃSKA, J. (eds.): Flora Slodkowodna Polski 10. - 750 pp., Panstwowe Wydawnictowo Naukowe, Warsawa - Krakov.

WoŁowski, K. \& HindÁK, F. (2005): Atlas of Euglenophytes. - 136 pp., Veda, Warsaw.

(C) Czech Phycological Society

Received November 30, 2009

Accepted January 25, 2010 